ОСОБЛИВОСТІ ЗАБЕЗПЕЧЕННЯ ПЕДАГОГІЧНОГО ПРОЦЕСУ НА КАФЕДРІ ЗАГАЛЬНОЇ ХІРУРГІЇ ІФНМУ В УМОВАХ ЗАГАЛЬНОНАЦІОНАЛЬНОГО КАРАНТИНУ

\title{
FEATURES OF PROVIDING OF PEDAGOGICAL PROCESS AT THE DEPARTMENT OF GENERAL SURGERY OF IFNMU IN THE CONDITIONS OF NATIONAL QUARANTINE
}

УДК 378.147+617+614.46

DOI https://doi.org/10.32843/2663-

$6085 / 2021 / 37.21$

\section{Симчич А.В.,}

канд. мед. наук,

доцент кафредри загальної хірургії Івано-Франківського національного медичного університету

\section{Джус О.В.}

докт. пед. наук, доцент, завідувачка кафедри професійної освіти та інноваційних технологій Прикарпатського національного університету імені Василя Стефаника

Гудз І.М.,

докт. мед. наук, профессор,

завідувач кафредри загальної хірургії Івано-Франківського національного медичного університету

Геник С.М.,

докт. мед. наук

професор кафедри загальної хірургії Івано-Франківського національного медичного університету
Статтю присвячено одній із найбільщих освітніх проблем XXI cm. - фрункціонуванню вищих навчальних закладів в умовах світовоі пандемії та загальнонаціонального карантину, запровадженого в Україні для запобігання розповсюдженню висококонтагіозного i надзвичайно небезпечного інфрекційного збудника вірусної природи.

Потреба у швидкому й якісному вирішенні такої ситуації виникла перед усіма навчальними закладами України. Терміновість була зумовлена тим, що проблема виникла в час навчального, а не канікулярного періоду, і перерив у навчанні міг призвести до непрогнозованих наслідків. Для закладів вищої освіти, які забезпечують навчальну діяльність у галузі знань «22 Охорона здоров'я», вирішити че питання непросто через велику кількість практичних навичок і умінь, які студент-медик може якісно опанувати тільки за умови традиційного стачіонарного навчання. Тобто для підготовки високопрофесійних фрахівців у галузі охорони здоров'я недостатньо мати тільки повний обсяг теоретичних знань. Їх ще слід закріпити практичними тренуваннями в учбовій аудиторії на манекенах і франтомах, у навчально-практичних центрах та біля ліжка хворого.

у статті висвітлено навчальні дисципліни які вивчають студенти третього, п'ятого і шостого курсів медичного фракультету та фракультету підготовки іноземних громадян на кафредрі загальної хірургії Івано-Франківського національного медичного університету (ІФНМУ). Надано детальну характеристику всіх чинників, які допомогли на етапі тимчасового переходу навчального процесу на кафредрі загальної хірургії ІФНМУ в онлайнформу. Описано особливості підготовки якісного методичного забезпечення і проведення практичних занять і читання лекцій в онлайнформаті. Запропоновано власну оцінку позитивних і негативних характеристик онлайннавчання студентів на кафедрі загальної хірурсії. Зроблено акцент на тому, що, незважаючи на наявність негативних характеристик онлайн-навчання студентів, така форма надання освітніх послуг уже буде постійною ефективною складовою частиною у структурі надання освітніх послуг незалежно від епідеміологічної ситуації в Україні та світі. Ключові слова: Івано-Франківський національний медичний університет, кафе- дра загальної хірургії, педагогічний процес, загальнонаціональний карантин.

The article is devoted to one of the biggest problems of the XXI century. This is the provision of educational services in a global pandemic and national quarantine, introduced in Ukraine to prevent the spread of highly contagious and extremely dangerous infectious agent of viral nature.

The need for a quick and high-quality solution to this situation has arisen before all educational institutions in Ukraine. Urgency was due to the fact that the problem arose during the educational period, not the holidays. And a break in learning could lead to unpredictable consequences. For higher education institutions that provide educational activities in the field of knowledge "22 Health Care" to solve this problem is not easy due to the large number of practical skills and abilities that a medical student can master only during offline learning. That is, for the student is not enough to have only theoretical knowledges to be a highly professional health professional. They still need to be consolidated by training on mannequins and phantoms in training centers and with the patient.

The article discriberes the disciplines which the third, fifth and sixth year students of the Medical Faculty and the Faculty of Training of Foreign Citizens are studied at the Department of General Surgery of Ivano-Frankivsk National Medical University (IFNMU). A detailed description of all the factors that helped at the stage of temporary transition of the educational process at the Department of General Surgery of IFNMU in the online form is given. Features of preparation of qualitative methodical maintenance and carrying out of practical employment and giving of lectures in an online format are described. The own estimation of positive and negative characteristics of online training of students at the department of general surgery is offered. Emphasis is placed on the fact that despite the negative characteristics of online student learning, this form of educational services will already be a permanent effective component in the structure of educational services, regardless of the epidemiological situation in Ukraine and in the world.

Key words: Ivano-Frankivsk National Medical University, Department of General Surgery, pedagogical process, national quarantine.
Постановка проблеми в загальному вигляді. Окрім великої кількості викликів і загроз життю людини, які наявні в сучасному світі, у XXI ст., на превеликий жаль, з'явилася ще одна дуже небезпечна проблема, яка стала прямою загрозою здоров'ю людини і вже забрала сотні тисяч людських життів. Це висококонтагіозний збудник вірус- ної природи, який до цього часу ще не вражав людину і тому в неї немає жодного сорормованого природнього захисту.

Домінуючі в медицині сьогодення аксіоми боротьби із захворюваннями говорять таке:

1 - найкращим методом лікування будь-яких захворювань є їх профрілактика; 
2 - якщо не вдалося запобігти захворюванню, то найбільш ефективним $є$ етіопатогенетичне лікування, що передбачає ліквідацію причин і механізмів або шляхів розвитку хвороби. У разі нового вірусного захворювання, яке набуло розмірів пандемії, нині найефективнішим засобом залишається профрілактика. Хоча за дуже короткий період часу зроблено величезний поступ у питанні як етологічного, так і патогенетичного ефективного лікування.

Отже, профрілактика найперше передбачає уникнення зараження збудником через унеможливлення його передачі від носія до здорової людини. Із цією метою 12 березня 2020 р. в Україні було оголошено загальнонаціональний карантин. На виконання його умов усі аспекти людської співпраці, які до цього передбачали особистісний взаємозв'язок, були припинені і трансорормовані (де це можливо) в дистанційну або онлайн-срорму. Не стали винятком і заклади вищої освіти, у тому числі й Івано-Франківський національний медичний університет та всі його структурні підрозділи.

Аналіз останніх досліджень і публікацій. Сьогодні $€$ дуже велика когорта науково-дослідницьких публікацій на тему дистанційної освіти як окремої форми навчання в закладах вищої освіти в Україні та за її межами. Вони надають детальну характеристику всіх аспектів провадження такої форми надання освітніх послуг [1, с. 3-11].

Тут важливе розуміння того, що дистанційна освіта як окрема фрорма навчання, яка вже десятиліттями використовується у світі й Україні, $€$ стандартною, прогнозованою, методично забезпеченою і такою, що не викликає жодної стурбованості ні у викладачів, ні у студентів. Більше того, багато елементів дистанційного навчання знайшли широке застосування в денній та заочній формах надання освітніх послуг [1, с. 6]. Та велика кількість освітніх закладів, особливо медичних, використовує лише денну форму навчання. I це було стандартом до моменту оголошення загальнонаціонального карантину.

Після 12 березня 2020 р. все раптово зміни лося, і вони змушені були терміново заміняти на час карантину денну форму на онлайн-навчання. Тому кількість публікацій, що торкаються цього питання, є ще невеликою як на теренах України, так і в ІФНМУ зокрема. Нас у першу чергу цікавили роботи колег 3 інших кафедр університету. Одні з них уважають, що введення в освітній процес дистанційного навчання у сучасних закладах освіти різних типів спонукатиме до перегляду змісту, структури і мети процесу навчання і для цього слід створити певну систему [2, с. 137]. В іншій роботі вказується на певний дискоморорт у студентів, особливо фракультету підготовки іноземних громадян. Останні в анонімному анкетуванні засвідчили про стан хронічного напруження і перебування у стані соціального стресу, що зумовлений не лише новими умовами життя, а й частими змінами між періодами живого спілкування на заняттях та умовами дистанційного навчання [3, с. 120-121]. Ще одна публікація детально описує етапи тимчасового переходу на дистанційну форму навчання в університеті, зокрема сумісного застосування технології синхронного і асинхронного типів дистанційного навчання. Відповідно до цього, задіяли платорорму Microsoft Teams, яка робить можливим поєднання цих двох фрорм дистанційного навчання [4 с. 1]. Тобто перші враження, перші аналіз і висновки тимчасової трансфрормації навчального процесу на онлайн-срорму $\epsilon$ як спільними в багатьох аспектах, так і багато в чому відмінними між собою.

У зв'язку із цим ми також не можемо не поділитися нашим досвідом упровадження різних форм дистанційного навчання в освітній процес на кафедрі загальної хірургії.

Виділення не вирішених раніше частин загальної проблеми. Заслуговують особливої уваги питання збереження мотивації студентів до навчання незалежно від форми навчання, їх самопідготовки, адаптації наявного технічного забезпечення до роботи в онлайн-орорматі, збереження кінцевого рівня знань у студентів, засвоєння і володіння практичними навичками й уміннями в умовах тимчасового переходу на фрорми дистанційного навчання.

Мета статті. Мета статті - проаналізувати процеси, якими супроводжувалася тимчасова зміна навчання на кафедрі загальної хірургії ІФНМУ 3 денної на онлайн-фрорму.

Виклад основного матеріалу. На кафедрі загальної хірургії Івано-Франківського національного медичного університету (ІФНМУ) студенти III курсу медичного фракультету (МФ) та фракультету підготовки іноземних громадян (ФПІГ) спеціальності 222 «Медицина» в V семестрі вивчають дві дисципліни: «Загальна хірургія» (Модуль 1 3,0 кредити) та «Сестринська практика» (Модуль 2 1,0 кредит). Студенти 5-6-го курсів у X-XII семестрах МФ та ФПІГ (спеціальності 222 «Медицина») вивчають дисципліну «Хірургія» (Модуль 2. Змістовий модуль 2 «Судинна хірургія» - 1,5 кредити та Модуль 5. Змістовний модуль 3 - 3,0 кредити). Окрім цього, п'ятикурсники обох фракультетів упродовж IX-X семестрів проходять (на вибір) на кафедрі вибіркові дисципліни «Клінічна практика. Блок 17» (Модуль 1 - 1,25 кредитів) або «Профресійна практика. Блок 17» (Модуль 1 - 1,25 кредитів) та вибіркову дисципліну «Судинна хірургія» (3 кредити). Навчальні програми по кожній із дисциплін $є$ ідентичними як для студентів - громадян України, так і студентів - громадян інших держав. Останні навчаються українською, англійською і російською мовами. Найбільше іноземних студентів 
навчаються англійською мовою. I 3 кожним роком це число зростає, що свідчить про високий рівень надання освітніх послуг в ІФНМУ.

Вищенаведена коротка характеристика доводить, наскільки великим є обсяг інорормації, кількість практичних навичок і вмінь, які студенти щорічно опановують на кафедрі загальної хірургіï.

Запровадження карантинних обмежень у світі й Україні зумовило гостру необхідність підготовки методичного і технічного забезпечення, освоєння нових комп'ютерних технологій для того, щоб перейти на навчання у форматі «онлайн». Для кафедри такі вимоги часу щодо тимчасової зміни форми навчання не становили суттєвих труднощів завдяки таким чинникам:

1. У кожній учбовій аудиторії на кафедрі $€$ персональний комп'ютер (ПК), який підключений до мережі Internet кабельним або Wi-Fi-зв'язком (фото 1).

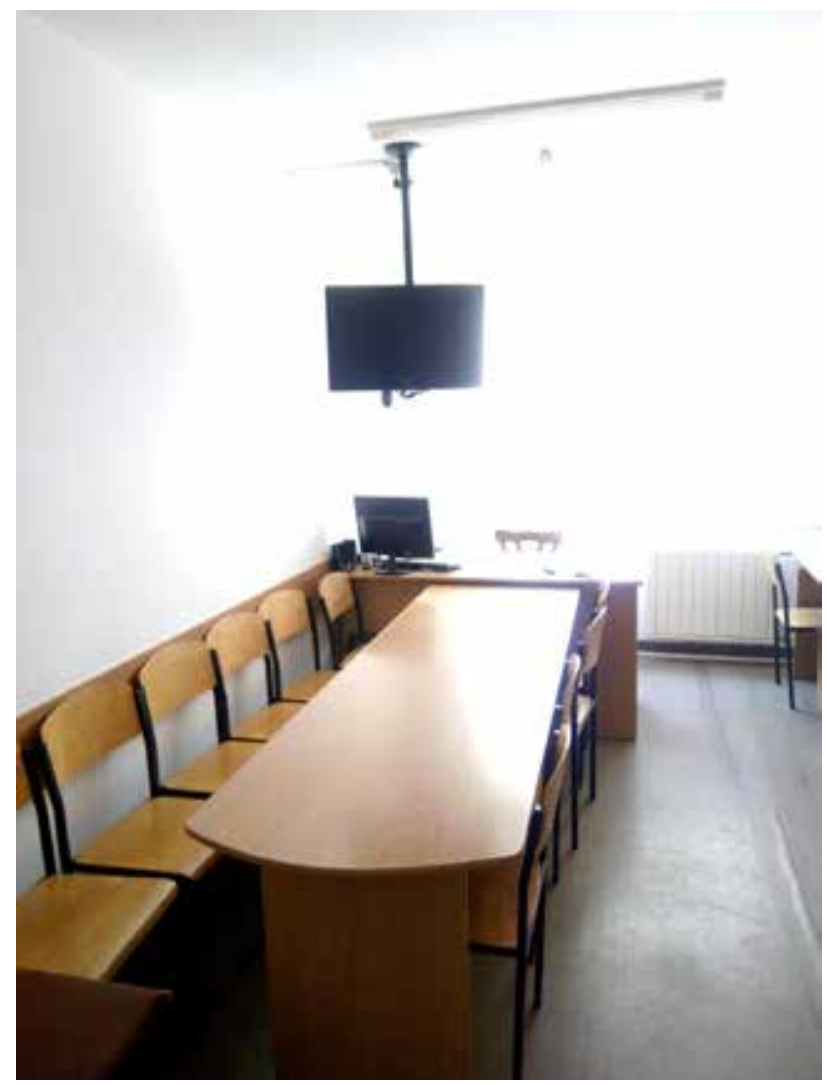

Фото 1. Учбова кімната, оснащена персональним комп'ютером, який підключений до мережі Internet кабельним зв'язком

2. Окрім ПК, учбові кімнати оснащені телевізійними передавачами, розмір екрану яких $є$ достатнім для того, щоб камера ПК могла якісно фріксувати відеокартинку з телевізійного передавача і передавати її для студентів, які у цей час онлайн перебувають на занятті (фоото 2).

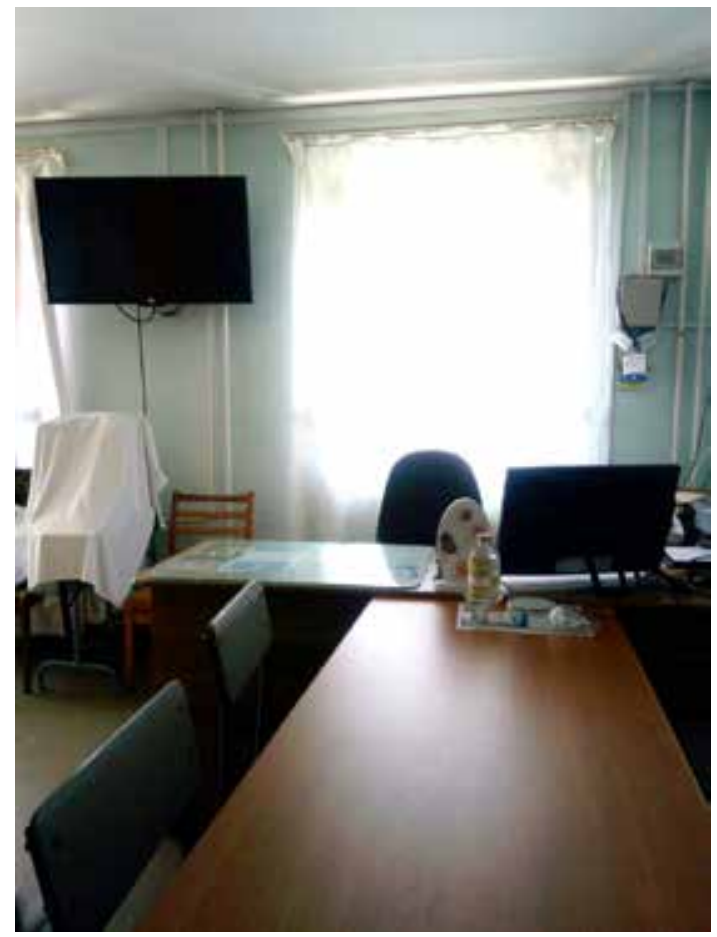

Фото 2. Учбова кімната, оснащена телевізійним передавачем

3. Каредра загальної хірургії закріплена за відділенням судинної хірургії ОКЛ м. Івано-Франківськ, в операційній якого наявна відеокамера останнього покоління, що здатна зближувати фрокус зображення на відстань до 50 см від операційного поля пацієнта (фото 3).

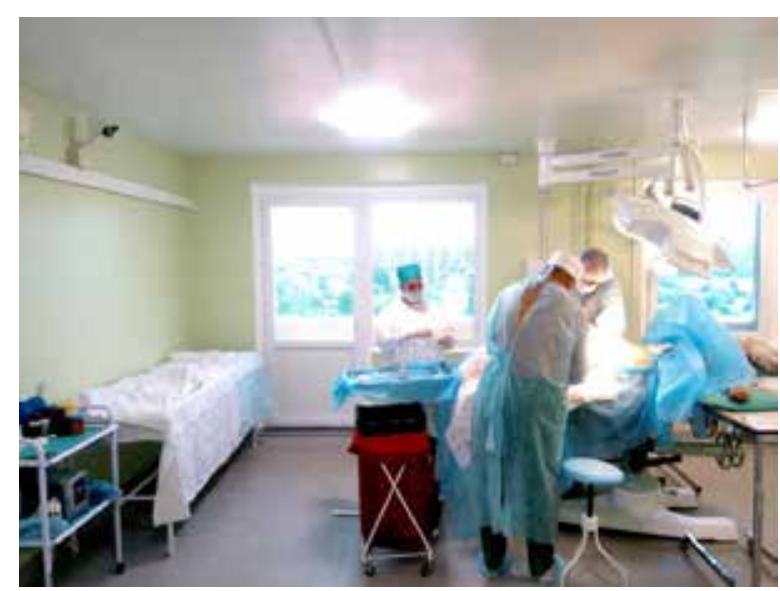

Фото 3. Відеокамера в операційній відділення судинної хірургії

На кожну учбову аудиторію здійснюється пряма відеотрансляція оперативних утручань, які в реальному часі відбуваються одночасно з проведенням заняття на кафредрі, це дає змогу студентам опановувати велику кількість практичних навичок, що відносяться до всіх аспектів роботи в операційній: санітарно-епідемічні режими, 
підготовка хворого до операції, виконання місцевої чи загальної анестезії, підготовка операційного поля, інтубація пацієнта, використання апарату штучної вентиляції легень, здійснення операційного доступу, операційного прийому, виходу з операції, накладання анастомозів, перев'язка судин, методи тимчасової і кінцевої зупинки кровотеч тощо (фото 4).

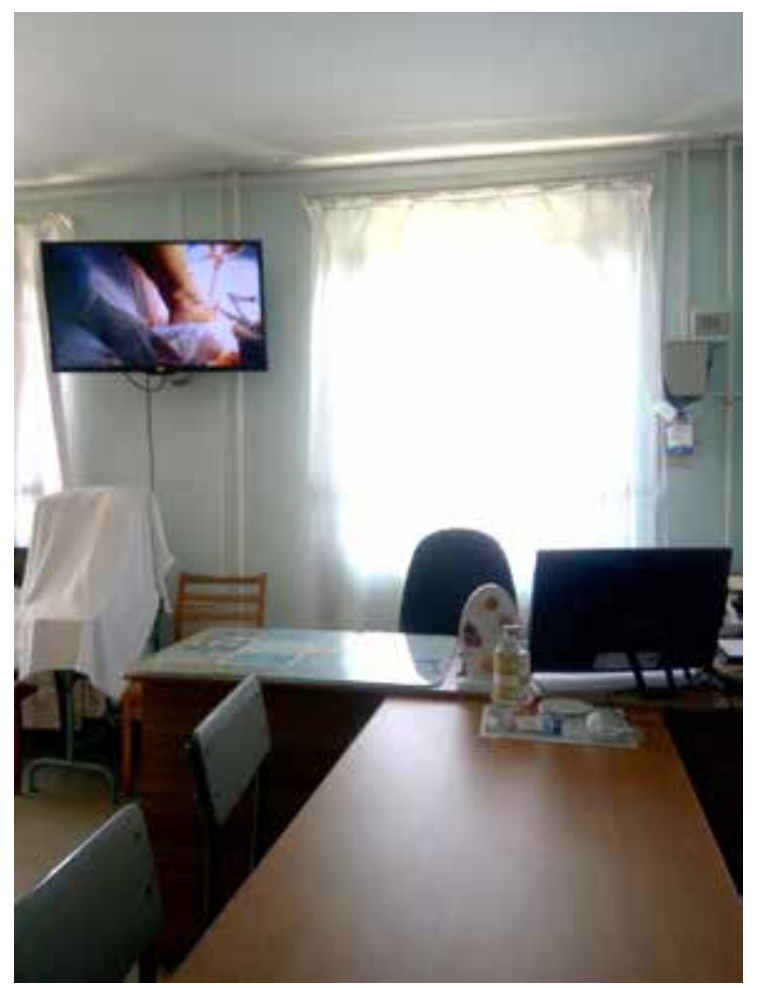

Фото 4. Відеотрансляція оперативного втручання наживо

4. Завдяки високоефективній і якісній реалізації ректоратом, Ученою радою та адміністрацією університету стратегії на постійний розвиток ІФНМУ в усіх аспектах діяльності працівники університету і студенти на період навчання мають виняткову можливість безкоштовно користуватися всіма програмними продуктами корпорації Microsoft (хмарними технологіями, навчальними програмами, електронною поштою, платформою Teams для проведення онлайн-занять тощо); усі ці продукти тісно взаємозв'язані між собою, що значно полегшує роботу з будь-якою інсрормацією.

5. Високий професіоналізм працівників інорормаційно-аналітичного центру ІФНМУ, які в найкоротші терміни зуміли забезпечити доступну й якісну підготовку професорсько-викладацького складу і студентів до навчання у форматі онлайн.

6. Відданість своїй справі і фраховість усіх працівників кафедри загальної хірургії, які дали змогу своєчасно і в повному обсязі підготувати методичне забезпечення як для читання лекцій, так i для проведення практичних занять.
Отже, у період загальнонаціонального карантину викладачі працювали онлайн на своєму робочому місці, але тривалий період часу змушені були проводити онлайн-заняття з дому через заборону відвідування кафедри у зв'язку погіршенням епідеміологічної ситуації. Звичайно, що в обох випадках освітні послуги надавалися якісно й ефективно, проте вагомим недоліком була неможливість вивчення і засвоєння тематичних практичних навичок і вмінь як у навчальних аудиторіях, так і в навчально-практичних центрах університету і біля ліжка хворого.

Незважаючи на ці обмеження, викладачами кафедри за нетривалий період часу було сорормовано необхідну базу навчального відеоматеріалу, як підготовленого самостійно, так і підібраного із загальнодоступних Інтернет-ресурсів. Це надало можливість студентам отримати належне теоретичне підґрунтя для вивчення і засвоєння практичних навичок і вмінь по всіх темах занять. У міру відновлення аудиторного навчання, а особливо роботи навчально-практичних центрів університету, студенти кінцево закріпили алгоритми виконання практичних навичок і їх застосування в практичній діяльності.

Уважаємо також за необхідне охарактеризувати позитивні і негативні аспекти навчання студентів на кафредрі загальної хірургії в онлайнфрорматі. Позитивними складниками, на нашу думку, є такі:

1) збереження здоров'я студентів, працівників університету і нашої кафредри в умовах пандемії завдяки мінімізації безпосередніх контактів та розповсюдження інфекції;

2) надзвичайно важливим $€$ психологічний аспект: студенти не перервали свою основну повсякденну діяльність, тобто навчання, й основне - в них не було ментальної перестороги, пов'язаної з ризиком заразитися збудником, що $є$ неможливим в умовах онлайн-навчання;

3) вагоме зростання професійної майстерності викладачів завдяки освоєнню методик користування багатьма комп'ютерними технологіями, програмними продуктами тощо, які раніше застосовувалися значно рідше;

4) максимально можливо зменшений дефріцит надання освітніх послуг студентам через тимчасовий перехід на онлайн-фрорму навчання;

5) значно простіше і легше стало зв'язатися зі студентом чи колегою для з'ясування виробничих питань завдяки відеозв'язку чи відеоконференції і т. д., тобто зменшилася потреба в безпосередніх зустрічах;

6) програмне забезпечення для проведення онлайн-навчання дає змогу одномоментно залучати максимально необхідну кількість студентів: читання лекцій, проведення практичних занять, засідань студентського наукового гуртка чи 
студентської науково-практичної конфреренції 3 міжнародною участю тощо;

7) більше того, у зв'язку з пандемією, велика частина студентів-іноземців повернулися додому, але завдяки онлайн-навчанню, зокрема використовуючи можливості, надані компанією Microsoft, нам удалося зберегти цілісність і ефективність надання освітніх послуг незалежно від того, в якій країні перебуває наш студент.

Недоліками, притаманними онлайн-навчанню, вважаємо такі:

1) найосновніші - це відсутність безпосередньої комунікації і взаємодії як між студентом і викладачем, так і між студентами, що є дуже важливим чинником як підвищення внутрішньої мотивації студентів до засвоєння необхідного матеріалу, так і кращого його запам'ятовування;

2) онлайн-фрорма навчання в тих самих часових рамках, що і офрфлайн-форма, характеризується більшою втомлюваністю і студентів і викладачів через необхідність постійного статичного перебування біля комп'ютера чи іншого пристрою зв'язку;

3) щодо останнього, то значно ефективніше студенти навчаються біля персонального комп'ютера, ніж використовуючи планшет чи мобільний телефон, оскільки робота не 3 персональним комп'ютером завжди дає більше психологічне навантаження (концентрація уваги тощо) та навантаження на зір - це і технічні можливості пристрою, і роздільна здатність екрану, і розмір зображення чи тексту тощо;

4) можливість користуватися планшетами чи телесронами, тобто не бути «прив'язаним» до приміщення, де є стаціонарний комп'ютер, зумовила неодноразові випадки, коли, з одного боку, студент присутній на онлайн-занятті, а $з$ іншого фактично у цей момент у силу обставин він змушений перебувати в транспорті, на вулиці і т. п., що значно знижувало ефективність навчання;

5) недоліком, спільним для офрдлайн- і онлайннавчання $€$ те, що сучасні пристрої та можливості Інтернет-ресурсів дають змогу студентам дуже швидко віднаходити потрібну інорормацію - на жаль, іноді це є та інформація, яку студент повинен опанувати і володіти нею під час підготовки до заняття вдома, а не відшукувати її в час заняття;

6) звичайно, що прогнозованими недоліками були й $€$ якість Інтернет-зв'язку, можливість поодинокими студентами, які вміло воло- діють комп'ютерними технологіями, впливати на Інтернет-зв'язок (відключати звук, зображення, видаляти без дозволу з онлайн-зустрічі когось 3 учасників, чи навіть викладача);

7) це рідкісні випадки, більше того, завдяки постійному навчанню фрахівцями ІАЦ університету профресорсько-викладацького складу всі працівники оволоділи технологічними методиками захисту і попередження подібних студентських хитрощів.

Висновки. Таким чином, зважаючи на всі вище описані особливості надання освітніх послуг в онлайн-фрорматі в умовах пандемії та загальнонаціонального карантину, можна абсолютно обґрунтовано стверджувати таке:

1 - як вивчення дисциплін, що викладаються на кафедрі загальної хірургії, так і в цілому якісне, ефективне і повноцінне здобуття профресії лікаря $€$ неможливим тільки 3 використанням онлайннавчання;

2 - залучення в освітній процес технологій дистанційного навчання дає змогу передусім зберегти здоров'я всіх учасників цього процесу, а по-друге, дуже суттєво збільшити можливості як надання інфрормації студентам, так і їх самостійного оволодіння всіма знаннями і вміннями, які передбачені навчальними програмами, і в підсумку стати високопрофресійним лікарем;

3 - незважаючи на наявність негативних характеристик онлайн-навчання студентів, така фрорма надання освітніх послуг уже буде постійною, невід'ємною й ефективною складовою частиною у структурі надання освітніх послуг незалежно від епідеміологічної ситуації в Україні та світі.

\section{БІБЛІОГРАФІЧНИЙ СПИСОК:}

1. Дистанційне навчання, переваги, недоліки, питання організації: рекомендаційний список літератури / уклад. І.А. Каліниченко. Запоріжжя, 2021. 12 с.

2. Аналіз особливостей дистанційного навчання та можливість його повноцінної інтеграції у навчальний процес / І.К. Чурпій та ін. Art of Medicine. 2020. № 4. С. $135-139$.

3. Пюрик М.В. Дистанційне навчання як вид соціального стресу у студентів фракультету підготовки іноземних громадян. Art of Medicine. 2020. № 4. С. 120-123.

4. Дистанційне навчання під час карантину. Як ІФНМУ долає безпрецедентні виклики пандемії : вебсайт. URL: https://www.ifnmu.edu.ua/uk/3071 (дата звернення: 13.06.2021). 